\title{
Future-proofing accounting education: Educating for complexity, ambiguity and uncertainty
}

\author{
Nicholas McGuigan ${ }^{1}$ \\ (D) https://orcid.org/0000-0002-0491-2504 \\ Email: nicholas.mcguigan@monash.edu
}

${ }^{1}$ Monash University, Monash Business School, Department of Accounting, Melbourne, Australia

\section{INTRODUCTION}

Coronavirus disease 2019 (COVID-19) is causing the largest disruption of the post-war era (McCalman, 2020; Snowden, 2020). It is changing the way human populations live and work across the planet, representing significant uncertainty. The pandemic is placing pressure on our economies, health systems, and global mobility (Giordano, 2020). It is transforming the way we interact with each other, our systems of local and global governance, and how we consume and value resources. The global pandemic is demonstrating how integrated our social and ecological systems are and is questioning the role we play in managing them. In short, the past year and a half is calling for us to adopt a systems perspective of the world, with redesigned models of accountability and governance that enable us to withstand the varied ecological, sociological and economic challenges of the coming decades.

But is this pressure really new? It seems it has been building up for some time. External factors, such as climate change, sustainability, food security, the future of work, technological innovation, political instability, refugee migration, and the over-consumption of resources all represent systemic economic, ecological, and sociological factors that place pressure on current business models, including the accounting profession and their models of accountability and governance. These systemic factors have led to the development of systems approaches of accountability such as the United Nations Sustainable Development Goals (UN SDGs), the Global Reporting Initiative's (GRI) non-financial measure indicators, Natural Capital Protocol, Social and Human Capital Protocol, and Integrated Reporting that all call for the balancing and integration of multiple ecological, social, and economic resources.

These future-oriented, integrated systems of governance and accountability seek to develop futureproof approaches to define, measure, account for and mediate value. This in turn is forcing the accounting 
profession to question: What is meant by value and measurement today and in the future? How can we account for "creative economies"? What role does accounting play in new technologies? What world will future accountants be accounting for? How do accountants embrace new forms of human behavior and contribute to new ways of organizing and governing?

We all are forced to rethink our past socially constructed models, including accounting, and to search for new solutions to human organizing, measuring, and valuing that account for the realities we now face: crises, uncertainty, and paradox. This requires a more integrated way of viewing business.

An integrated approach means that organizational resources are viewed holistically as a system, where an impact on one resource will affect another, with those interconnections needing to be managed accordingly. There will be conflicting priorities between the different resources, compromises to be made, and these will need to be carefully thought through and designed in a way that results in a successful balance.

In this changing global environment, business professionals of tomorrow will need to be comfortable with increasing degrees of complexity. Accounting education will need to move towards educating for complexity, ambiguity, and uncertainty. Developing integrative thought will require accounting graduates to become comfortable with complexity, possess an ability to adapt to new situations, and be agile enough to approach problems with an openness to novel, hitherto unimaginable perspectives (Miller, 1981). In other words, accounting education needs to drastically open up.

\section{TOWARDS A BROADENING OF ACCOUNTING EDUCATION}

Accounting education at universities is typically taught over a number of educational levels, graduate and undergraduate, and to varying student cohorts. Students majoring in accounting tend to complete a three- to four-year degree that includes various aspects of accounting and supporting courses. The nature of undergraduate accounting degrees tend to emphasize the technical aspects of accounting. A broadening of accounting education involves less of a technical focus and more of an emphasis on a conceptual understanding of accounting (Braun, 2004).

The broadening of accounting education has introduced two foci, namely, "professional skills" and "professional values, ethics and attitudes", which aim to extend accounting education to that of a learned profession. The International Accounting Education Standards Board (IAESB, 2015, p. 28) describes professional skills as consisting of "intellectual, interpersonal and communication, personal, and organizational skills". Professional values, ethics, and attitudes complement these skills through

the professional behaviour and characteristics that identify professional accountants as members of a profession. They include the principles of conduct (i.e., ethical principles) generally associated with and considered essential in defining the distinctive characteristics of professional behaviour. (IAESB, 2015, p. 28)

Placing an emphasis on professional scepticism, the development of an inquiring mind and an awareness and application of social and political contexts are shown as important components of an accountant's education. Further, the IAESB (2015, p. 72) in its International Education Standards, pronounced the formal inclusion of reflective practice in designing learning and development activities for accountants:

Reflective activity is the iterative process by which professional accountants, at all stages of their career, continue to develop their professional competence by reviewing their experiences (real or simulated) with a view to improving their future actions.

Thus, there is a clear acknowledgement of a growing shift from an emphasis on technical skills and competencies to an increasing awareness of students' self-development capabilities. When accounting, bookkeeping and payroll clerks, and auditors continue to lead the World Economic Forum's list of "top job roles in decreasing demand across industries", it is not surprising that the accounting profession has been questioning the relevance and suitability of their workforce and recruiting accordingly (World Economic Forum, 2020). In 2015, Ernst \& Young (United Kingdom), announced a reduction in their university degree entry criteria for employment in an effort to broaden their recruitment pool (Sherriff, 2015). This shift in skill development is particularly important when considering the degree of digital disruption impacting our profession (Susskind, 2020; Susskind \& Susskind, 2015). New pathways and opportunities will be created where the future accountant 
takes on, for example, the role of a "digital curator" of business information, providing contextual relevance and guidance through the maze of increasingly "data"focused business environments.

Professions of the future will require graduates to transcend traditional disciplinary boundaries, hold high degrees of resilience, agility, creativity, social intelligence, and be able to think in novel, integrated, and adaptive ways (Goos et al., 2019). In fact, the Future of Jobs Report 2020 shows the top ten skills for 2025 as analytical thinking and innovation; active learning and learning strategies; complex problem-solving; critical thinking and analysis; creativity, originality, and initiative; leadership and social influence; technology use monitoring and control; technology design and programming; resilience, stress tolerance, and flexibility; and reasoning, problem-solving, and ideation (World Economic Forum, 2020).

Numerous professional accounting bodies' reports over time, together with various professional accreditation guidelines acknowledge the need for a shift towards a broader accounting education [see, for example, Roy and MacNeill (1967), American
Accounting Association (AAA, 1986), Accounting Education Change Commission (AECC, 1990), Behn (2012), and O'Connell et al. (2015)]. However, these reports, guidelines and standards fail to acknowledge that a shift from a technical emphasis towards self- and professional development capabilities requires an entirely different view of education altogether.

This change in accounting education relies on the implementation of innovative teaching techniques that abandon procedural tasks and memorizing of financial standards in favor of a more reflective form of learning that assists in the development of learners' capabilities. Skills and capabilities that focus on self-development, selfreflection, creativity and design mindset, critical awareness and adaptability, transdisciplinary appreciation, and an ability to think in integrated ways occurs when students activate and create their own learning development. To better equip graduates for the professions of the future learner-centered accounting curricula that provides opportunities for students to actively shape, discover, and explore their own professional identities and careers is required.

\section{ACTIVATING ACCOUNTING EDUCATION THROUGH CONSTRUCTIVIST DEVELOPMENTAL PEDAGOGY}

Constructivist learning is epistemologically positioned in viewing the world with multiple knowledge interpretations and construction. Learning is therefore both contextual and relational, it is about making meaning, which is personal and unique to the individual. For as Biggs (2003, p. 13) states:

\footnotetext{
Learning is thus a way of interacting with the world. As we learn, our conceptions of phenomena change, and we see the world differently. The acquisition of information in itself does not bring about such change, but the way we structure that information and think with it does.
}

Developing skills and capabilities, such as those indicated above, that focus on self-development requires accounting graduates to possess a heightened awareness of themselves as professionals and commit to continuous learning, self-development, and renewal. Therefore, "students must be given the opportunity to develop their own personal and collective positions on accounting issues, and to discover possibilities for activating those positions through praxis" (Boyce et al., 2012, p. 66). To move to this new learning paradigm accounting education needs to shift in focus, away from what teachers teach and more towards how learners learn (Harwood \& Cohen, 1999).

Baxter-Magolda's $(1992,1999)$ constructivistdevelopmental pedagogy provides a pedagogical framework that enables such a shift through a joint exploration of learning. She found, through longitudinal studies, that a change in an individual's learning involves beliefs about oneself and their relation to others. She argues that this process involves the simultaneous development of three distinct aspects, namely: cognitive - how an individual conceives knowledge; interpersonal - how an individual views oneself in relation to others; and intrapersonal - how one perceives one's sense of identity. This requires a willingness on behalf of the learner to question authoritative figures to develop their own viewpoint and provide them with the affirmation required to express their own voice.

Baxter-Magolda (1992) argues for students to acknowledge the "orientation" of their study, finding ways in which to make it their own. From this body of work, she distilled a pedagogical framework, constructivist-developmental pedagogy that focuses on three core educational principles for designing learning 
experiences: validate students as knowers; situate learning in the students' experience; value learning as the mutual construction of meaning between students and educator.

\subsection{Validate Students as Knowers}

This first principle requires accounting educators to validate their students as knowers, acknowledging their students have prior understandings and experiences, and that these are the physically necessary starting point for any further learning. Accounting students therefore should be enabled to express their points of view, actively bringing these into the classroom, reflecting on them, and discussing them together with their peers. The educator has a role to facilitate discussion amongst students, deeply listen to their students and assist them in expressing their own views.

This provides an opportunity for accounting educators to open up the accounting curricula, imaging diverse ways in which to engage students, and learn more about what students bring with them into the classroom, their prior understandings, and various experiences. This can range from simple brainstorming activities on different accounting concepts through visual collage construction of what accounting means to them, to asking students to take photographs of what it means to be professional. In this way, teaching becomes equally a way to facilitate a student's ability to connect and relate what they encounter in formal accounting education with what they already know.

\subsection{Situate Learning in the Students' Experience}

Secondly, learning needs to be situated within the lived experiences of students. A deeper understanding of how students relate to and contextualize accounting is needed. This means accounting educators need to be curious about the world accounting students live within, willing to listen and to reflect on questions, such as "What kind of world do young people inhabit?", "What is the nature of their beliefs?" and "What is considered valuable and important within their orientation towards their social world?" Accounting educators then need to engage with the students' lifeworld, making use of the students' own experiences, lives and current understandings as a way of contextualizing learning.

\subsection{Learning as the Mutual Construction of Meaning between Students and Educator}

Finally, learning is seen as a mutual construction of meaning between students and educator. Learning therefore becomes a journey of joint self-discovery between students and educator, through a shared appreciation of experience and evidence. This last principle changes the role of the accounting educator, becoming a guide, assisting students to make meaning of their learning experiences and connect this new understanding to prior ways of thinking. In this way, the accounting educator is an active learner as much as the students, where they can equally learn from each other.

\subsection{Constructivist-Developmental Pedagogy in Action}

An illustrative example depicting the use of BaxterMagolda's constructivist-developmental pedagogy can be found in the persistence of accounting stereotypes which, if unaddressed, can cause students to emphasis technical detail, objectivity, and rationalism, rather than seeing accounting as a system requiring judgement, interpretation, and critical analysis. This can be addressed by staging learner experiences in varying contexts of the self, society/nature, and the organization/accounting profession. For students to develop an understanding of accounting as a system they may need to first explore a system they can relate to, both validating the knowledge students bring and to situate the learning in the student's context. This is demonstrated by the following three stages as implemented in a sustainability accounting course at the author's university.

Firstly, students are presented with the Ikigai model (meaning sense of purpose) and asked to use this as an analytical tool to reflect on accounting as a career. Ikigai presents a personal systems framework and reflective tool that asks students to explore the four overlapping areas profession, vocation, mission, and passion. Students consider what they can be paid for, what they are good at, what the world needs and what they love doing. Working within this framework enables students to reflect on a topic they are familiar with - themselves -, assessing the development of their graduate attributes, gaining a deeper appreciation of themselves with all their complexity and contradictions, elements commonly found in complex systems. 
Secondly, a shift in context is provided when accounting students and educators engage in joint self-discovery as they explore together a natural eco-system, visiting a local permaculture garden. On this occasion, sustainable development faculty introduce them to the permaculture ethics and design principles. Permaculture, an abbreviation for permanent agriculture, was developed by Bill Mollison and David Holmgren in Australia, during the 1970s. Permaculture is a human design system comprising of three ethics and 12 design principles that can be used to design self-sustaining ways of living. See for example, Mollison (1988).

Together, students and educators explore a natural ecosystem through a permaculture lens, contrasting this with the human design system of accounting and its business context. The natural environment provides students with an understanding of the complex and interconnected nature of systems. An application of permaculture design principles provides students with examples of when judgements, compromises, and decisions are needed to be made within a system. In turn, these learning experiences enable students to come back into the seminar with a newfound appreciation to discuss the implications of this for accounting as a system.

Finally, students are asked to choose a listed company to critically analyze its sustainability reporting and map its performance to the UN SDGs. Students match the UN SDGs to organizational information, identify performance measures, and discuss varying forms of assurance including the professional judgement, interpretation, and critical analysis that is required.

\section{DECONSTRUCTING AND PLAYFULLY REIMAGINING ACCOUNTING EDUCATION}

A challenge constructivist-developmental pedagogy presents to accounting educators is the need to start deconstructing their practice and playfully reimagining what is possible for accounting education. Educating individuals for complexity, ambiguity, and uncertainty requires more creative and exploratory forms of education, where students discover accounting for themselves, are exposed to more integrated learning contexts, engage in inquiry-based learning experiences across disciplines, and are afforded opportunities to grow capabilities related to their own self-development.

Constructivist-developmental pedagogy invites accounting educators to work creatively to design individualized learning experiences that connect to students unique lived experiences, encouraging learning self-awareness and critical reflection. This is all to be achieved within a mass higher education environment that is currently built for standardized education. Achieving this is of course not going to be easy and will present distinct challenges, but perhaps part of the way forward is realizing that there is unlikely to be a standard approach or a single way in which to achieve this.
Deconstructing one's practice and reimagining what is possible in accounting education can best be achieved when accounting educators possess an openness to new practices and ways of educating, hold a curiosity to learn from their own experiences and those of other disciplines and have the courage to experiment and take risks with their teaching practice. Therefore, it will be important for accounting educators to engage in a process of reflective unlearning. Unlearning as a pedagogical tool is often used in the areas of addiction and rehabilitation, where there is significant need to unlearn unhelpful processes and habits. However, there is potential for a wider application where unlearning can apply to the ability to open oneself up to new possibilities, new ways of seeing and critical reflection of one's learning and teaching practice. Unlearning encompasses an ability to critically deconstruct more traditional views and perceptions of accounting, placing them in context with current and future business environments to derive new meaning and understandings. This is an important first step in opening up the accounting discipline to further align with new ways of thinking and operating, required for the future of business and accounting professions. 


\section{FINAL REMARKS}

Accounting education research has shown accounting educators hold a variety of epistemological beliefs, and therefore variation in conceptions of what learning and teaching involves is common in accounting education (Leveson, 2004; Lucas, 2002). If or when discussion on epistemological beliefs and/or ways of teaching accounting occurs, it is predominantly amongst educational peers. However, in the context of a constructivist-developmental pedagogy, it may be in the best interests of accounting educators and students for such discussions to occur inside "classrooms", jointly and collaboratively with students. For it might be that students are best placed to assist accounting educators engage in a process of reflective unlearning.

Doing so calls into question hierarchies associated with typical knowledge exchange. Institutional learning has traditionally maintained a commonly accepted hierarchy as to who is teaching and who is learning, however in environments of complexity, ambiguity, and uncertainty these roles are fluid, adaptable, and subject to change in different contexts. Learning and teaching are therefore no longer seen as static processes, and it remains important to consider how spaces can be made more versatile and adaptable to suit diverse needs. For this, it might be helpful to playfully question our own views of education and the norms we have come to operate within.
- What constitutes knowledge?

- How do we unlearn?

- What is the role of understanding in accounting education?

- How does play influence pedagogy?

- How does space transform the way we teach and learn?

- What role do accounting educators have in connecting students with their lived experiences?

Educating for increasing complexity, ambiguity, and uncertainty requires accounting educators to (re)turn to thinking more about learning and to consider other ways in which knowledge is constructed. In facilitating learner-led curation of learning materials and resources, accounting educators will be inviting students to navigate their own conceptions and understandings of accounting. Students become more responsible for the selection, organization, and nurture of their own learning. Guided reflective practice through the use of, for example, play, democratic dialogue, informal learning, collective learning, counter-narratives, critical discourse, cross-disciplinary experience, and creativity provides accounting students with an opportunity to unpack their beliefs and ideas related to accounting, critically discuss these with each other and form new conceptual understandings that will better prepare them to navigate the complexity, ambiguity, and uncertainty of their own futures.

\section{REFERENCES}

Accounting Education Change Commission. (1990). Objectives of education for accountants: Position statement no. 1. Issues in Accounting Education, 5(2), 307-312.

American Accounting Association. (1986). Committee on the future structure content, and scope of accounting education (The Bedford Committee). Future accounting education: Preparing for the expanding profession. Issues in Accounting Education, 1(1), 168-195.

Baxter Magolda, M. (1992). Knowing and reasoning in college: Gender related patterns in students' intellectual development. Jossey-Bass Publishers.

Baxter Magolda, M. (1999). Creating contexts for learning and selfauthorship: Constructive-developmental pedagogy. Vanderbilt University Press.

Behn, B. K., Ezzell, W. F., Murphy, L. A., Rayburn, J. D., Stith, M. T. \& Strawser, J. R. (2012). The Pathways Commission on
Accounting Higher Education: Charting a national strategy for the next generation of accountants. Issues in Accounting Education, 27(3), 595-600.

Biggs, J. (2003). Teaching for quality learning at university (2nd ed.). Open University Press.

Boyce, G., Greer, S., Blair, B., \& Davids, C. (2012). Expanding the horizons of accounting education: Incorporating social and critical perspectives. Accounting Education: An International Journal, 21(1), 47-74.

Braun, N. M. (2004). Critical thinking in the business curriculum. Journal of Education for Business, 79(4), 232-236.

Giordano, P. (2020). How contagion works: Science, awareness and community in times of global crises. Weidenfeld \& Nicolson.

Goos, M., Arntz, M., Zierahn, U., Gregory, T., Gomez, S. C., Vazquez, I. G., \& Jonkers, K. (2019). The impact of 
technological innovation on the future of work (no. 2019/03) [Working Paper]. JRC Working Papers Series on Labour, Education and Technology. https://www.econstor.eu/ bitstream/10419/202320/1/jrc-wplet201903.pdf

Harwood, E. M., \& Cohen, J. R. (1999). Classroom assessment: Educational and research opportunities. Issues in Accounting Education, 14(4), 691-724.

International Accounting Education Standards Board. (2015). International education standards framework. International Federation of Accountants.

Leveson, L. (2004). Encouraging better learning through better teaching: A study of approaches to teaching in accounting, Accounting Education: An International Journal, 13(4), 529548.

Lucas, U. (2002). Contradictions and uncertainties: Lecturers' conceptions of teaching introductory accounting. British Accounting Review, 34(3), 183-203.

McCalman, J. (2020). It's possible. In E. Dawson \& J. McCalman (Eds). What happens next? (pp. 15-22). Melbourne University Press.

Miller, A. (1981). Integrative thinking as a goal of environmental education. The Journal of Environmental Education, 12(4), 3-8.
Mollison, B. (1988). Permaculture: A designer's manual. Tagari Publishers Limited.

O’Connell, B., Carnegie, G., Carter, A., de Lange, P., Hancock, P., Helliar, C., \& Watty, K. (2015). Shaping the future of accounting in business education in Australia. CPA Australia.

Roy, R., \& MacNeill, J. H. (1967). Horizons for a profession: The common body of knowledge for certified public accountants. American Institute of Certified Public Accountants.

Sherriff, L. (2015). Ernst \& Young removes degree classification from entry criteria as there's 'no evidence' university equals success. The Huffington Post. http://www.huffingtonpost. co.uk/2015/08/04/ernst-and-young-removes-degreeclassification-entry-criteria_n_7932590.html

Snowden, F. M. (2020). Epidemics and society: From the black death to the present, Yale University Press.

Susskind, D. (2020). A world without work. Allen Lane.

Susskind, R., \& Susskind, D. (2015). The future of the professions: How technology will transform the work of human experts. Oxford University Press.

World Economic Forum (2020). The Future of Jobs Report 2020. http://www3.weforum.org/docs/WEF_Future_of_Jobs_2020. pdf 